\title{
Appropriateness of admission to two intensive care units at alexandria main university hospital, egypt
}

\author{
R Abuyadek ${ }^{1}$, H Helmy $^{1}$, AM Fayed ${ }^{2 *}$, M Abdelwahab $^{3}$, D Fouad ${ }^{1}$ \\ From ESICM LIVES 2015 \\ Berlin, Germany. 3-7 October 2015
}

\section{Introduction}

Resource allocation and problem of inappropriate admissions in ICUs has been a global concern. No studies were found in Egypt to investigate it.

\section{Objectives}

Assessment of appropriateness of admission to two intensive care units, through assessment of; adherence to guidelines of ICU admission recommended by Society of Critical Care Medicine (SCCM) [[1]], severity of illness of admitted patients using APACHE II [[2]] score, utilization of ICU resources and outcome of ICU admission [3].

\section{Methods}

The study was conducted in ICUs of Alexandria Main University Hospital, medical records of the adult patients admitted to the ICUs from 2013-2014, were the target population; 324 patients were included. Data collection methods; concurrent review in ICUs during patient admission, to capture day one clinical data for calculation of APACHE II score and reviewing day one ICU specific interventions received and retrospectively in medical record department after patient discharge from the hospital for retrieval of data related to outcome of ICU admission episode.

\section{Results}

The demographic characteristics and administrative data of the patients admitted were studied. Regarding age the highest percent of cases (43.8\%) were belonging to age category $50-<70$ years old. Regarding sex, $59.6 \%$ were males. Most common source of admission was ER (89.5\%), About $92.9 \%$ of the sample was medical admissions. Approximately $42 \%$ of them were admitted in the night shift.

${ }^{2}$ Alexandria University, Faculty of Medicine, Critical Care Medicine, Alexandria, Egypt

Full list of author information is available at the end of the article
Nearly, all of them were adherent to diagnosis model of SCCM guidelines of ICU admission and approximately $75 \%$ were adherent to objective parameters model of SCCM guidelines. Mean APACHE II score of admitted cases was $13.84 \pm 6.861$. Outcome of ICU admission episode; $39.8 \%$ of sample patients were died, while $33.3 \%$ were transferred to hospital ward, about $22 \%$ were discharged against medical advice. Use of ICU specific interventions in the first 24 hours of admission was assessed. About $18 \%$ of cases didn't receive ICU specific treatment in the first 24 hours of admission. A comparison was done between patients who didn't receive ICU active treatment in the first 24 hours of admission to ICU and those who received regarding age, APACHE II score, ICU length of stay and outcome of ICU admission.

\section{Conclusions}

Selection of patients is nearly appropriate, but rationing towards selected groups is recommended.

\section{Grant Acknowledgment}

No grants received

\author{
Authors' details \\ ${ }^{1}$ Alexandria University / High Institute of Public Health, Health Administration \\ and Behavioral Sciences, Alexandria, Egypt. ${ }^{2}$ Alexandria University, Faculty of \\ Medicine, Critical Care Medicine, Alexandria, Egypt. ${ }^{3}$ Alexandria University / \\ High Institute of Public Health, Department of Biostatistics, Alexandria, Egypt. \\ Published: 1 October 2015

\section{References} \\ 1. Egol A, Fromm R, Guntupalli KK, Fitzpatrick M, Kaufman D, Nasraway S, et al: \\ Guidelines for intensive care unit admission, discharge, and triage. Crit \\ Care Med 1999, 27(3):633-638. \\ 2. Knaus WA, Draper EA, Wagner DP, Zimmerman JE: APACHE II: a severity of \\ disease classification system. Crit Care Med 1985, 13(10):818-829. \\ 3. Miranda DR, de Rijk A, Schaufeli W: Simplified Therapeutic Intervention \\ Scoring System: the TISS-28 items-results from a multicenter study. Crit \\ Care Med 1996, 24(1):64-73.
}

(c) 2015 Fayed et al.; This is an Open Access article distributed under the terms of the Creative Commons Attribution License (http:// creativecommons.org/licenses/by/4.0), which permits unrestricted use, distribution, and reproduction in any medium, provided the original work is properly cited. 
doi:10.1186/2197-425X-3-S1-A478

Cite this article as: Abuyadek et al:: Appropriateness of admission to two intensive care units at alexandria main university hospital, egypt. Intensive Care Medicine Experimental 2015 3(Suppl 1):A478.

\section{Submit your manuscript to a SpringerOpen ${ }^{\circ}$ journal and benefit from:}

- Convenient online submission

- Rigorous peer review

- Immediate publication on acceptance

- Open access: articles freely available online

- High visibility within the field

- Retaining the copyright to your article

Submit your next manuscript at $\gg$ springeropen.com 